Tropical Journal of Pharmaceutical Research February 2013; 12 (1): 39-44

ISSN: $1596-5996$ (print); 1596-9827 (electronic)

(c) Pharmacotherapy Group, Faculty of Pharmacy, University of Benin, Benin City, 300001 Nigeria.

All rights reserved.

Available online at http://www.tjpr.org

Original Research Article

http://dx.doi.org/10.4314/tjpr.v12i1.7

\title{
Comparison of Flow-Through Cell and Paddle Methods for Testing Vaginal Tablets Containing a Poorly Water-Soluble Drug
}

\section{Emilia Szymanska and Katarzyna Winnicka*}

Department of Pharmaceutical Technology, Faculty of Pharmacy, Medical University of Bialystok, Mickiewicza 2c, 15-222 Bialystok, Poland

*For correspondence: E-mail: kwin@umb.edu.pl; Tel: +48-857485616

Received: 31 January 2012

Revised accepted: 26 November 2012

\begin{abstract}
Purpose: To evaluate the usefulness of the flow-through cell apparatus for testing commercial vaginal tablets containing poorly water-soluble clotrimazole.

Methods: The effect of experimental conditions (type of dissolution medium, flow rate and positioning of the tablet) on the dissolution profile of clotrimazole were examined and optimal parameters for conducting the experiments were determined. The amount of drug released was analyzed by high performance chromatography (HPLC) at $210 \mathrm{~nm}$. The usefulness of the flow-through cell apparatus was compared to FDA recommended paddle apparatus.

Results: Using acetate buffer pH 5.2 containing 1 \% SDS, both methods gave different dissolution profiles. The paddle apparatus tended to give faster rate of dissolution (approx. $88.5 \%$ during the first 20 min of the experiment), which was probably caused by higher agitation and greater surface area of the drug-dissolution medium in a vessel. In the flow-through cell method, total drug release was definitely slower and was observed after 2 to $5 \mathrm{~h}$; at a flow rate of $16 \mathrm{ml} / \mathrm{min}$, more than $80 \%$ of the drug dissolved after 30 min of the test. It was noticed that raising the flow rate of the dissolution medium caused significantly higher drug release.

Conclusion: The results demonstrate that the flow-through cell method is reproducible and can be successfully used for evaluating in vitro dissolution of clotrimazole from non-modified release tablets. The slower rate of dissolution obtained in the flow-through cell method would help to distinguish between different formulations.
\end{abstract}

Keywords: Dissolution test, Flow-through cell method, Paddle method, Clotrimazole

Tropical Journal of Pharmaceutical Research is indexed by Science Citation Index (SciSearch), Scopus, International Pharmaceutical Abstract, Chemical Abstracts, Embase, Index Copernicus, EBSCO, African Index Medicus, JournalSeek, Journal Citation Reports/Science Edition, Directory of Open Access Journals (DOAJ), African Journal Online, Bioline International, Open-J-Gate and Pharmacy Abstracts

\section{INTRODUCTION}

In vitro dissolution study is an official test for evaluating drug release from tablet and capsule dosage forms. It is important in process control, quality assurance and to determine reliable release characteristics of the product over time $[1,2]$. Dissolution tests have also been applied as a tool to predict drug product performance in vivo as a result of attempts to minimize costly in vivo bioequivalence studies required to approve a new drug product [3,4]. The basket and paddle methods are currently the most widely used dissolution techniques. However, both display several disadvantages, e.g., hydrodynamic disturbance or finite sink conditions $[5,6]$.

The flow-through cell apparatus is a relatively new method for dissolution studies and has been officially included in the United States and European Pharmacopeia as apparatus 4 [2,7]. It consists of a pump which forces the release 
medium upwards through a vertically positioned flow-through cell, a water bath and a reservoir filled with the release medium [8,9]. In spite of the fact that a variety of combinations and the diversity of available cell types allow the application of this apparatus for testing wide range of dosage forms, the flow-through cell method is particularly favoured for the in vitro dissolution studies of poorly water-soluble drugs and sustained release dosage forms due to its ability to maintain sink conditions during the test $[5,8]$. In the flow-through cell method, there are no problems with sampling and no further filtration steps are needed as the sample solution is automatically filtered upon leaving the cell [5]. Although there are many reports in the literature describing the suitability of apparatus 4 as dissolution method for various dosage forms [1012], no standard pharmacopeial tests on the use of this apparatus for non-modified release drugs are available $[2,7,13]$. Therefore, the aim of this study was to evaluate the usefulness of the flowthrough cell method (apparatus 4) for testing commercially available vaginal tablets containing a poorly water-soluble drug, clotrimazole, intended for immediate drug release vis-a-vis the FDA recommended paddle method [13]. Since the United States and European Pharmacopeia provide only limited information about apparatus 4 test conditions, the influence of some experimental parameters, such as type of dissolution medium, flow rate and positioning of the tablet, on the dissolution profile of clotrimazole was also examined.

\section{EXPERIMENTAL}

\section{Materials}

Clotrimazole was kindly given by Aflofarm, Pabianice, Poland. Acetic acid (80 \%), hydrochloric acid (35 - $38 \%$ ), sodium acetate, potassium dihydrogen phosphate, sodium hydroxide and disodium hydrogen phosphate were obtained from Chempur, Piekary Slaskie, Poland. Sodium dodecyl sulfate (SDS) was purchased from $\mathrm{POCH}$, Gliwice, Poland. Methanol (HPLC grade) was purchased from Merck, Darmstadt, Germany. Water for HPLC was distilled and passed through a reverse osmosis system (Milli-Q Reagent Water System, Billerica, USA). Commercially available vaginal tablets containing clotrimazole $100 \mathrm{mg}$ were purchased locally (Clotrimazolum GSK, GlaxoSmithKline Pharmaceuticals SA, batch no: RB 2361, expiry date: 02.2014). The excipients in formulating the tablets include lactose monohydrate, potato starch, adipic acid, sodium bicarbonate, magnesium stearate, colloidal silicon dioxide, sodium dodecyl sulphate.

\section{Clotrimazole solubility studies}

The solubility of clotrimazole was checked in different media - distilled water, $0.1 \mathrm{M} \mathrm{HCl}(\mathrm{pH}$ 1.4, acetate buffer ( $\mathrm{pH} 5.2)$ and acetate buffer (pH 5.2) incorporating $1 \%$ SDS. Excess amount of the drug $(5 \mathrm{mg})$ was placed in a glass conical flask with $20 \mathrm{ml}$ of appropriate medium. The flasks were agitated for $24 \mathrm{~h}$ in a shaker water bath at $25 \pm 0.5^{\circ} \mathrm{C}$ at a speed of $250 \mathrm{rpm}$. The saturated drug solution was centrifuged at 4000 rpm for $20 \mathrm{~min}$. Samples $(1 \mathrm{ml})$ were withdrawn from the supernatant, suitably diluted with methanol, filtered through a $0.45 \mu \mathrm{m}$ CA (cellulose acetate) membrane filter paper (GVS Filter Technology, Indianapolis, IN, USA) and analyzed by high performance liquid chromatography (HPLC) (Agilent Technologies 1200, Agilent, Waldbronn, Germany). All experiments were conducted in triplicate.

\section{Disintegration time study}

Disintegration study of the vaginal tablets was carried out according to European Pharmacopeia [2] in $0.1 \mathrm{M} \mathrm{HCl}$ or acetate buffer ( $\mathrm{pH} 5.2)$ with 1 $\%$ SDS, maintained at $37 \pm 0.5{ }^{\circ} \mathrm{C}$. A disintegration tester, Electolab ED-2L (India) consisting of a basket-rack assembly, was used. Six tablets were used in each test. Complete disintegration of the tablets was observed visually and the time taken was noted.

\section{Dissolution study by paddle method (apparatus 2)}

Vaginal tablets with clotrimazole were placed directly into six vessels of the dissolution tester (Erweka Paddle Dissolution Tester, type DT $600 \mathrm{HH}$, Heusenstamm, Germany), each containing $900 \mathrm{ml}$ of the dissolution medium (Table 1). Samples $(5 \mathrm{ml})$ were withdrawn at predetermined time intervals, filtered through a $0.45 \mu \mathrm{m}$ CA filter paper, diluted with methanol and analyzed by HPLC. Withdrawn samples were replaced with equivalent volume of fresh dissolution medium. Studies were conducted in triplicate.

\section{Dissolution study by flow-through cell method (apparatus 4)}

Erweka Flow-Through Cell Dissolution Tester, type DFZ 720 (Heusenstamm, Germany) equipped with $22.6 \mathrm{~mm}$ diameter cells was used. One glass bead of $5 \mathrm{~mm}$ diameter and $5 \mathrm{~g}$ of beads of $1 \mathrm{~mm}$ diameter were placed in the sample cell to fill the bottom conical part. Vaginal tablets were situated either directly on glass 
beads or positioned uniformly in a tablet clip holder to determine the effect of positioning the dosage form within the cell. The appropriate release medium was circulated in an open-loop configuration, so fresh medium was continuously pumped through the flow cell. The effect of flow rate on drug release was evaluated at flow rates between 4 and $16 \mathrm{ml} / \mathrm{min}$. Fractions of the dissolution medium were collected and at the predetermined time points $1 \mathrm{ml}$ samples were withdrawn, diluted with methanol and analyzed by HPLC. Studies were carried out in triplicate.

Table 1: Dissolution test conditions used for the test methods

\begin{tabular}{lcc}
\hline Parameter & Paddle & $\begin{array}{c}\text { Flow-through } \\
\text { cell }\end{array}$ \\
\hline $\begin{array}{l}\text { Dissolution medium } \\
\text { Temperature }\end{array}$ & $\begin{array}{c}0.1 \mathrm{M} \mathrm{HCl} \text { or acetate buffer } \\
\mathrm{pH} 5.2+1 \% \text { SDS }\end{array}$ \\
$\begin{array}{l}\text { Paddle rotation } \\
\text { Flow rate }\end{array}$ & $50 \mathrm{rpm}^{*}$ & - \\
Rotation speed & - & 4,8 or $16 \mathrm{ml} / \mathrm{min}$ \\
Sampling & - & $120 \mathrm{rpm}$ \\
& 10,20, & $10,20,30,45$ \\
& 30,45 & $\mathrm{~min} ;$ \\
metection & $\mathrm{min}^{*}$ & $1,2,3,4,5 \mathrm{~h}$ \\
\hline FDA recommendation $[13]$ & $\mathrm{HPLC}$ at $\lambda=210 \mathrm{~nm}$ \\
\hline
\end{tabular}

\section{HPLC analysis of clotrimazole}

The concentration of clotrimazole in the dissolution medium was determined by a HPLC system (Agilent Technologies 1200) equipped with a G1312A binary pump, a G1316A thermostat, a G1379B degasser and a G1315B diode array detector (Agilent, Waldbronn, Germany). Data collection and analysis were performed using Chemstation 6.0 software. Isocratic separation was achieved on a Zorbax Eclipse XDB-C18, 4.6x150 mm, $5 \mu \mathrm{m}$ column (Agilent, Waldbronn, Germany). Mobile phase was methanol - phosphate buffer $(\mathrm{pH} 7.4,4: 1$ $\mathrm{v} / \mathrm{v}$ ), flow rate $1.0 \mathrm{ml} / \mathrm{min}$ and UV detection was performed at a wavelength of $210 \mathrm{~nm}[14,15]$. Column temperature was maintained at $25 \stackrel{\circ}{\circ}$. For injection into the HPLC system, $20 \mu \mathrm{l}$ of sample was used. All reagents used for analysis were of HPLC grade. The retention time of clotrimazole was $5.2 \mathrm{~min}$. Standard solutions for calibration curve were prepared in $0.1 \mathrm{M} \mathrm{HCl}$ or in acetate buffer ( $\mathrm{pH}$ 5.2) incorporating $1 \%$ SDS.

\section{Statistical analysis}

The results were expressed as mean \pm standard deviation (SD). The analysis was performed using the analysis of variance (ANOVA) and multiple comparisons were made to check statistical significance using Statistica 8.0 software. Differences were considered to be statistically significant at $p<0.05$.

\section{RESULTS}

\section{Solubility of clotrimazole}

The solubility of clotrimazole in distilled water and acetate buffer pH 5.2 without surfactant (SDS) was very low, being 0.38 and $4.46 \mu \mathrm{g} / \mathrm{ml}$, respectively, but much higher in $0.1 \mathrm{M} \mathrm{HCl}(527.0$ $\mu \mathrm{g} / \mathrm{ml}$ ) and in acetate buffer $\mathrm{pH} 5.2$ containing 1 $\%$ SDS $(527.4 \mu \mathrm{g} / \mathrm{ml})$.

\section{Tablet disintegration time}

Complete disintegration of the tablets in $0.1 \mathrm{M}$ $\mathrm{HCl}$ was occurred after $5 \pm 0.4 \mathrm{~min}$, and in acetate buffer pH 5.2 containing $1 \%$ SDS, this was achieved after $8 \pm 0.6 \mathrm{~min}$.

\section{In vitro release by paddle method}

Figure 1 presents the dissolution profiles of clotrimazole in $0.1 \mathrm{M} \mathrm{HCl}$ and acetate buffer $\mathrm{pH}$ 5.2 containing $1 \%$ SDS obtained by paddle method.

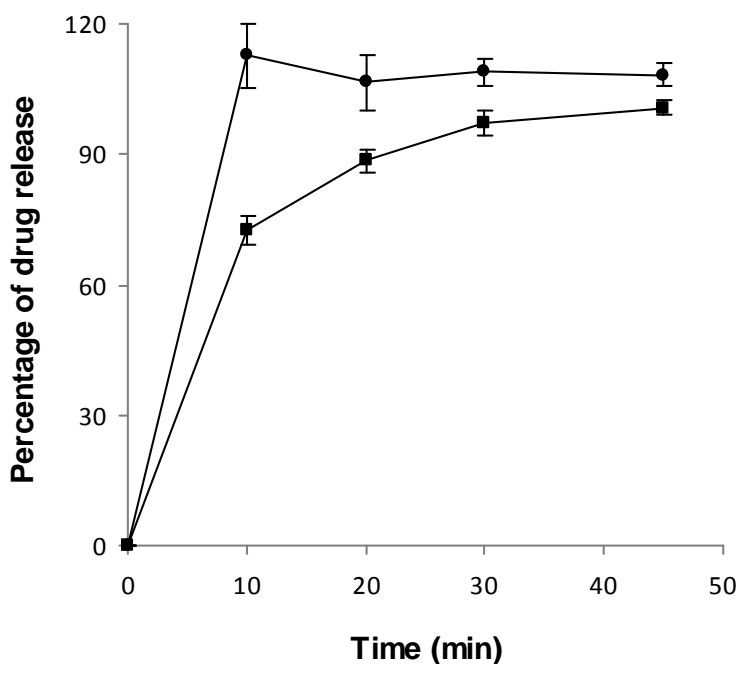

Figure 1: Clotrimazole dissolution profiles obtained by paddle method. Each value represents mean \pm SD ( $n$ =6) $(\mathrm{Key}: \mathbf{0}=0.1 \mathrm{M} \mathrm{HCl} ; \mathbf{\square}=$ acetate buffer $\mathrm{pH} 5.2$ with $1 \%$ SDS)

Faster release was observed in the medium recommended by FDA $(0.1 \mathrm{M} \mathrm{HCl})[13]$ in which $100 \%$ of the drug dissolved during the first $10 \mathrm{~min}$ of the test. In acetate buffer containing surfactant (1\% SDS), $88.52 \%$ of clotrimazole was released during the first 20 min of the study.

Trop J Pharm Res, February 2013;12 (1): 41 


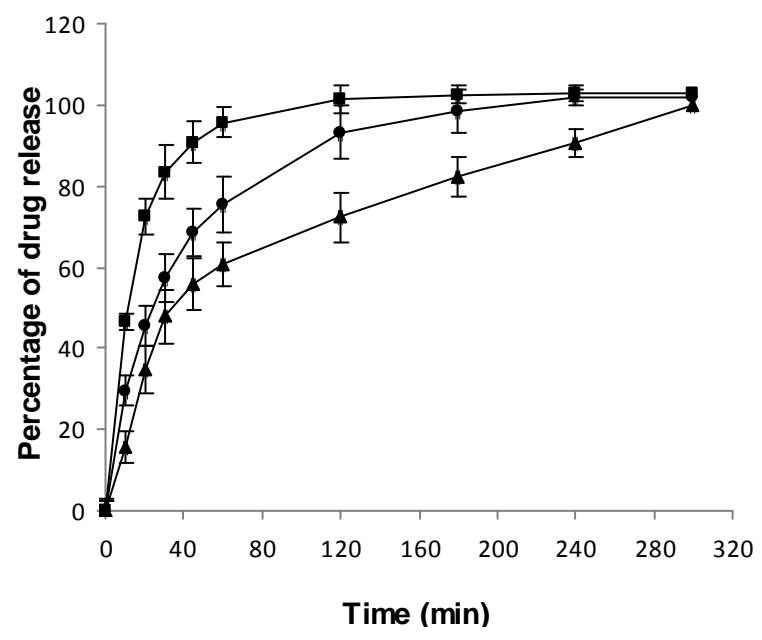

Figure 2: Clotrimazole dissolution profiles obtained by flow-through cell method in acetate buffer $(\mathrm{pH} \mathrm{5.2)}$ containing $1 \%$ SDS at flow rate of $4 \mathrm{ml} / \mathrm{min}(\boldsymbol{\Delta}) ; 8$ $\mathrm{ml} / \mathrm{min}(\bullet)$; and $16 \mathrm{ml} / \mathrm{min}(\bullet)$. Each value represents mean $\pm S D(n=6)$

\section{In vitro release by flow-through cell method}

Figure 2 shows a comparison of the dissolution profiles of clotrimazole obtained at various flow rates $(4,8$ and $16 \mathrm{ml} / \mathrm{min})$ in acetate buffer $(\mathrm{pH}$ 5.2) containing $1 \%$ SDS.

The fastest release was observed with the flow rate at $16 \mathrm{ml} / \mathrm{min}$, where about $83.4 \%$ of clotrimazole was released after $30 \mathrm{~min}$ of the investigation, whereas with the flow rate at 4 $\mathrm{ml} / \mathrm{min}$ and $8 \mathrm{ml} / \mathrm{min}$ only about $60.7 \%$ and $75.5 \%$ of the drug dissolved at the end of first hour. As it is presented in Figure 3, using apparatus 4, a faster release was observed in $0.1 \mathrm{M} \mathrm{HCl}-85.9 \%$ after $10 \mathrm{~min}$ of the experiment. In comparison with acetate buffer $\mathrm{pH}$ 5.2 with $1 \%$ SDS more than $80 \%$ of the drug was released during $30 \mathrm{~min}$.

Figure 4 represents dissolution profiles of clotrimazole in acetate buffer pH 5.2 containing 1 $\%$ SDS from tablets situated differently in the cell during the test.

It was noticed that rates of dissolution obtained for tablets placed uniformly in a clip holder or directly in glass beads were similar (83.4\% versus $85.7 \%$ ) after $30 \mathrm{~min}$ of the test.

\section{DISCUSSION}

Selecting a dissolution medium that suitably simulates in vivo conditions is one of the challenges in developing a good dissolution method. According to FDA guideline, $0.1 \mathrm{M} \mathrm{HCl}$ is advised as the dissolution medium for vaginal tablets of clotrimazole [13]. Based on solubility data, clotrimazole exhibited comparable solubility in $0.1 \mathrm{M} \mathrm{HCl}$ and acetate buffer $(\mathrm{pH} 5.2)$ containing $1 \%$ SDS.

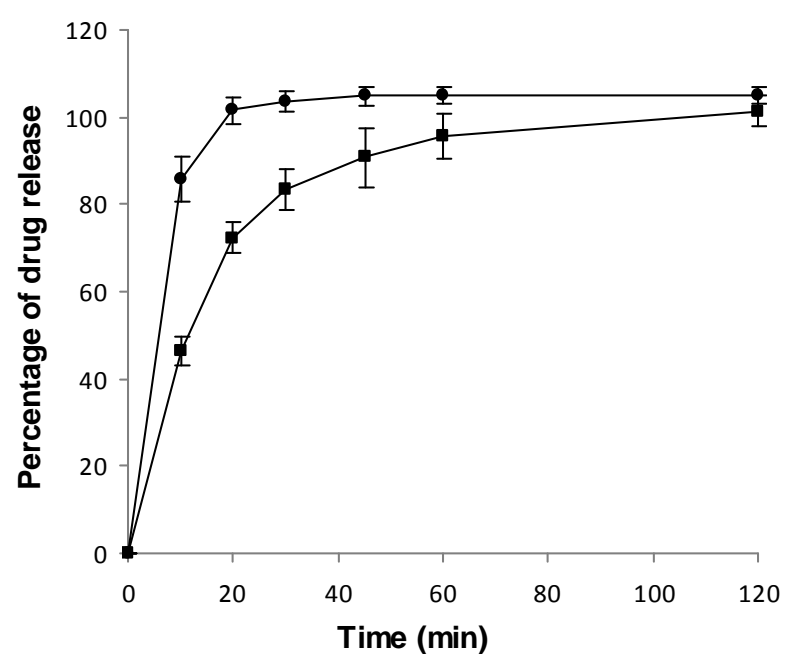

Figure 3: Clotrimazole dissolution profiles obtained by flow-through cell at constant flow rate of $16 \mathrm{ml} / \mathrm{min}$.in $0.1 \mathrm{M} \mathrm{HCl}(\bullet)$ and acetate buffer $\mathrm{pH} 5.2$ with $1 \%$ SDS

(匹). Each value represents mean $\pm \operatorname{SD}(n=6)$

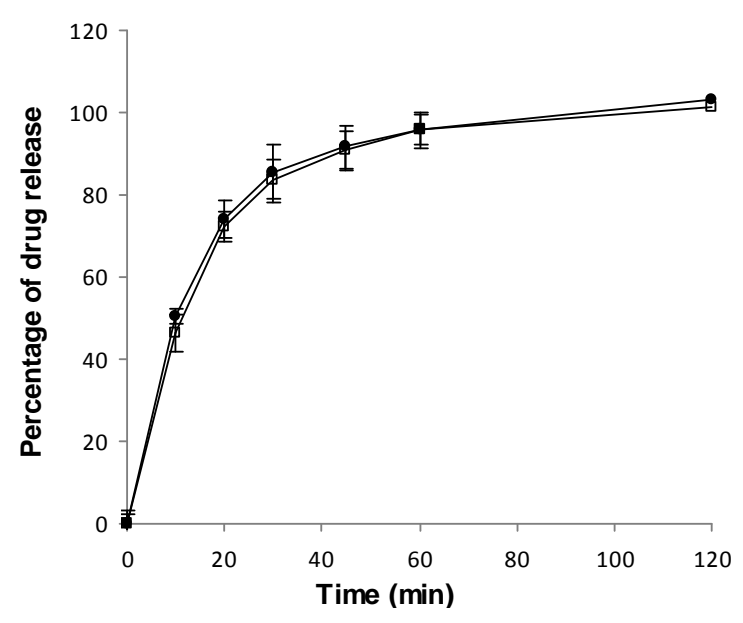

Figure 4: Clotrimazole dissolution profiles obtained by flow-through cell method in acetate buffer $\mathrm{pH} 5.2$ containing $1 \%$ SDS at a constant flow rate of 16 $\mathrm{ml} / \mathrm{min}$. The tablets were positioned uniformly in a clip holder $(\mathrm{F} 1, \bullet)$ or situated directly on the glass beads $(F 2, \boldsymbol{\varpi})$. Each value represents mean $\pm \operatorname{SD}(n=6)$.

$0.1 \mathrm{M} \mathrm{HCl}$ is strongly acidic with a $\mathrm{pH}$ of about 1.4 , which ordinarily would be an inadequate medium since it is not close to vaginal $\mathrm{pH}(\mathrm{pH} 4$ - 5) [16], and therefore, clotrimazole may eventually be degraded in such a harsh environment. Therefore, acetate buffer $\mathrm{pH} 5.2$ with $1 \%$ SDS was selected for further studies as the $\mathrm{pH}$ value better imitates vaginal conditions.

In the paddle method, it was found that although almost $100 \%$ of clotrimazole was released in $0.1 \mathrm{M} \mathrm{HCl}$ within the first $10 \mathrm{~min}$ of the test, a precipitation of components of the tablet in this 
medium occurred. As a result, the sampling process was hindered as the sampling probes withdrawing from the vessels were coated with the precipitates.

In the presence of acetate buffer $\mathrm{pH} 5.2$ containing $1 \%$ SDS, insoluble components were found to sediment just after disintegration of the tablet, so a transparent medium with no floating particles was observed during the dissolution studies. More than $80 \%$ of the drug was released during first $20 \mathrm{~min}$ of the study and the total amount of clotrimazole was released in 45 min - the limit recommended by FDA and European Pharmacopeias [2,7,13].

In the flow-through cell method, the time taken to achieve total drug release varied from 2 to $5 \mathrm{~h}$, and was affected mainly by the applied flow rate. It was observed that drug dissolution was a direct function of the flow rate. Significantly $(p<$ $0.05)$ faster release was noticed at a flow rate of $16 \mathrm{ml} / \mathrm{min}$, and hence this flow rate was used in further experiments.

Two media, $0.1 \mathrm{M} \mathrm{HCl}$ or acetate buffer $(\mathrm{pH} 5.2)$ containing $1 \%$ SDS gave different dissolution profiles in the paddle method, with the paddle method giving significantly $(p<0.05)$ higher dissolution rates. This is probably due to higher agitation rate and greater surface area of the drug-dissolution medium interface in the vessel. Similar observations were made in dissolution experiments with gelatin capsules containing a poorly water soluble amine drug [11]. In the flowthrough cell method faster release was observed in $0.1 \mathrm{M} \mathrm{HCl}(85.9 \%$ in $10 \mathrm{~min})$ when compared to the acetate buffer $\mathrm{pH} 5.2$ with $1 \%$ SDS (> 80 $\%$ of the drug released in $30 \mathrm{~min})$. The slower rate of dissolution observed in acetate buffer $(\mathrm{pH}$ 5.2) with $1 \%$ SDS is helpful to distinguish between different formulations and may be explained by longer disintegration time of the tablets in this medium. The total disintegration of the tablet in $0.1 \mathrm{M} \mathrm{HCl}$ and acetate buffer $\mathrm{pH} 5.2$ with $1 \%$ SDS was observed after about 5 and 8 $\min$, respectively.

Different positioning of tablets did not remarkably influence the dissolution profile of clotrimazole. The solid/liquid interface - the point of contact between fresh solvent and the surface of the solid - is the key dissolution parameter. The flowthrough cell apparatus can present different environments to the sample - without glass beads in the entry cone, turbulent conditions and using glass beads, laminar flow conditions have been achieved [17]. The tablet can be placed upon glass beads or with a wire holder facilitating placement of the tablet approximately midway along the cylindrical part. It was shown that various positioning of tablets did not remarkably influence the dissolution profile of clotrimazole indicating that when glass beads are used, laminar and homogenous flow are achieved and stable hydrodynamic conditions are provided. These results are comparable with previously reported studies on prednisone tablets, where where it was found that there was no difference in release rate when the tablet was left free on glass beads or placed in a clip holder [10].

\section{CONCLUSION}

Although the paddle method tended to give higher dissolution rates, the flow-through cell method showed reproducibility and may be successfully used for evaluating the in vitro dissolution of clotrimazole from non-modified release tablets. Flow rate and type of dissolution medium exert a fundamental influence on dissolution profile, but different positioning of the tablet in the cell did not have significant impact on release behaviour.

\section{REFERENCES}

1. Azarmi S, Roa W, Löbenberg R. Current perspectives in dissolution testing of conventional and novel dosage forms. Int J Pharm. 2007; 2: 12-21.

2. European Pharmacopeia. Directorate for the quality of Medicines \& Healthcare of the Council of Europe, Strasburg, 6th edition, 2007; Vol. 1: pp.266-275.

3. Emami J. In vitro-in vivo correlation: from theory to applications. J Pharm Pharmaceut Sci. 2006; 9: 169-189.

4. Shiko G, Gladden LF, Sederman AJ, Connolly PC, Butler JM. MRI studies of the hydrodynamics in a USP 4 dissolution testing cell. J Pharm Sci. 2011; 100: $976-991$

5. Baxter JL, Kukura J, Muzzio FJ. Shear-induced variability in the United States pharmacopeia apparatus 2: modification to the existing system. AAPS J. 2006; 7: E857-E864.

6. Langenbucher $F$, Benz $D$ Kurth $W$ Moller $H$, Otz $M$. Standardized flow-cell method as an alternative to existing pharmacopeial dissolution testing. Pharm Ind 1989; 51: 1276-1281.

7. The United States Pharmacopeia. The United States Pharmacopeial Convention, Baltimore, 32th edn, 2009; Vol 1: pp 263-272.

8. Singh I, Aboul-Enein HY. Advantages of USP Apparatus IV (Flow-through cell apparatus) in dissolution studies. J Iran Chem Soc 2006; 3: 220-222.

9. Bhardwaj U, Burgess DJ. A novel UP apparatus 4 based release testing method for dispersed systems. Int $J$ Pharm 2010; 388: 287-294.

10. Zhang $G H$, Vadino WA, Yang TT, Cho WP, Chaudry IA. Evaluation of the flow through cell dissolution apparatus: effects of flow rate, glass beads and tablet position on drug release from different types of tablets. Drug Dev Ind Pharm 1994; 20: 20632078.

11. Hu J, Kyad A, Ku V, Zhou P, Cauchon N. A comparison of dissolution testing on lipid soft gelatin capsules using USP apparatus 2 and apparatus 4. Dissol Tech. 2005; 12: 6-9. 
12. Zolnik B, Raton J-L, Burgess D. Application of USP apparatus 4 and in situ fiberoptic analysis to microsphere release testing. Dissol Tech. 2005; 12 . 11-14.

13. FDA - Recommended Dissolution Methods [homepage on the Internet]. U.S. Food and Drug Administration, U.S. Department of Health \& Human Services; [cited 2011 Dec 21]. Available from: http.//www.accessdata.fda.gov

14. Hájková $R$, Sklenářová $H$, Matysová $L$, Švecová $P$ Solich $P$. Development and validation of HPLC method for determination of clotrimazole and its two degradation products in spray formulations.
Talanta 2007; 73: 483-489.

15. Hashiguchi T, Kodama A, Ryu A, Otagiri M. Retention capacity of topical imidazole antifungal agents in the skin. Int J. Pharm. 1998; 161: 195-204.

16. Bachhav YG, Patravale VB. Microemulsion-based vaginal gel of clotrimazole: formulation, in vitro evaluation, and stability studies. AAPS PharmSciTech. 2009; 10: 476-481.

17. Brown W. Apparatus 4 flow through cell: some thoughts on operational characteristics. Dissol Tech. 2005; 5: 28-30. 